\title{
The role of Escherichia coli haemolysin in the pathogenic synergy of colonic bacteria in subcutaneous abscess formation in mice
}

\author{
T. USHIJIMA, M. TAKAHASHI and A. SETO
}

Department of Microbiology, Shiga University of Medical Science, Otsu, Shiga 520-21, Japan

\begin{abstract}
Summary. The growth of nine species of colonic bacteria-Escherichia coli, Enterococcus faecalis, Bacteroides ovatus, Fusobacterium varium, Clostridium perfringens, Klebsiella pneumoniae, Proteus vulgaris, Staphylococcus aureus and Bifidobacterium adolescentis - was examined after concomitant injection to form experimental subcutaneous abscesses in mice. Injection of a mixture of $c .10^{5} \mathrm{cfu}$ of each of the first five strains ( $E$. coli, Ent. faecalis, $B$. ovatis, $F$. varium and $C$. perfringens) resulted in abscess formation in all mice tested when the $E$. coli strain was haemolytic. $E$. coli and $B$. ovatus multiplied and reached a maximum population of $c .10^{8} \mathrm{cfu} / \mathrm{abscess}$. When non-haemolytic $E$. coli was used, injection of $\geq 10^{7} \mathrm{cfu}$ was required for abscess formation. The inclusion of partially purified $E$. coli haemolysin $\left(125 \mathrm{HU}_{50}\right)$ with c. $10^{5} \mathrm{cfu}$ of bacteria including non-haemolytic $E$. coli resulted in abscess formation in most mice tested. These results indicate that $E$. coli haemolysin is one factor that may potentiate pathogenic synergy among colonic bacteria especially between $E$. coli and $B$. ovatus, during abscess formation.
\end{abstract}

\section{Introduction}

A wide variety of aerobic and anaerobic bacteria has been isolated from infected foci, such as abscesses, caused by colonic flora. Escherichia coli and members of the fragilis group of Bacteroides are detected most frequently. ${ }^{1,2}$ Since these bacteria usually predominate in the colonic flora, their frequent isolation is to be expected. However, the reasons for the selective survival of $E$. coli and $B$. fragilis in such foci of infection are not clear. Many investigations have reported pathogenic synergy among aerobic and anaerobic bacteria. ${ }^{3-5}$ Verweijvan Vught et al. ${ }^{6}$ found synergy between $E$. coli and $B$. fragilis in abscess formation, and showed that the intensity of synergic activity was dependent on $E$. coli although the factors involved were not identified. In this study, the role of haemolysin produced by $E$. coli in the pathogenic synergy of nine bacterial species predominant in the colonic microflora was examined in a subcutaneous abscess model in mice.

\section{Materials and methods}

\section{Bacterial species}

Bacteria used were representative strains of seven predominant bacterial species of the human colon-E.

Received 15 Sep. 1989 ; revised version accepted 30 March 1990. coli ATCC 25922 (haemolytic) and ATCC 11775 (nonhaemolytic), Klebsiella pneumoniae ATCC 13883, Proteus vulgaris ATCC 13315, Enterococcus faecalis IFO 12969, B. ovatus SU 39, Fusobacterium varium ATCC 8501 and Bifidobacterium adolescentis ATCC 15703 - and two species resident in small numbers-Staphylococcus aureus ATCC 25923 and Clostridium perfringens VPI 5201. The last two bacteria are recognised pathogens but are rarely found in lesions caused by colonic flora. Bacteria were obtained from the American Type Culture Collection (ATCC), the Institute for Fermentation Osaka, Japan (IFO), the Anaerobe Laboratory, Virginia Polytechnic Institute and State University, Blacksburg, VA (VPI); $B$. ovatus was from our own laboratory (SU, Shiga University).

\section{Inocula}

The test strains were inoculated into $5 \mathrm{ml}$ of Gifu anaerobe medium (GAM) broth (Nissui Seiyaku Co. Ltd, Tokyo) and incubated anaerobically in an atmosphere of $\mathrm{CO}_{2} 10 \%, \mathrm{~N}_{2} 90 \%$ at $37^{\circ} \mathrm{C}$ for $18-20 \mathrm{~h}$. The culture was then centrifuged at $4000 \mathrm{~g}$ for $10-15 \mathrm{~min}$ at $5^{\circ} \mathrm{C}$ and the resulting sediment was suspended in $5 \mathrm{ml}$ of suspending medium so that the density was $\left(5 \times 10^{8}\right)-\left(1 \times 10^{9}\right) \mathrm{cfu} / \mathrm{ml}$ (c. McFarland tube no. 3-4); $0 \cdot 5-1 \cdot 0-\mathrm{ml}$ samples of the cell suspension of each test strain were pooled to form the mixtures. Mice were inoculated with $0.1 \mathrm{ml}$ of the original mixture or its appropriate dilution.

The suspending medium contained (/L) Trypticase Peptone (BBL) 10 g, Proteose Peptone No. 3 (Difco) $10 \mathrm{~g}$ 
Yeast Extract (BBL) $2 \mathrm{~g}$, chondroitin sulphate sodium salt (Tokyo Kasei, Tokyo) $1 \mathrm{~g}$, haemin (equine, type III; Sigma) $0.01 \mathrm{~g}$, glucose $1 \mathrm{~g}$, glycogen (oyster) $3 \mathrm{~g}, \mathrm{NaCl}$ $3 \mathrm{~g}, \mathrm{Na}_{2} \mathrm{HPO}_{4}$ (anhydrous) $5 \mathrm{~g}, \mathrm{KH}_{2} \mathrm{PO}_{4}$ (anhydrous) $2 \mathrm{~g}$, L-cysteine $\mathrm{HCl}-\mathrm{H}_{2} \mathrm{O} 0.5 \mathrm{~g}$, Tween $800.25 \mathrm{~g}$, and agar $1.5 \mathrm{~g}$ (all supplied by Nacalai Tesque, Tokyo). The $\mathrm{pH}$ of the medium was adjusted to 7.0 with $\mathrm{NaOH} 10 \% \mathrm{w} / \mathrm{v}$ and $\mathrm{HCl} 10 \% \mathrm{v} / \mathrm{v}$.

\section{Preparation of partially purified haemolysin}

Haemolysin was prepared according to the method of Ushijima $e t$ al. ${ }^{7}$ From a fresh culture of E. coli ATCC 25922 in Heart Infusion Broth (Nissui, Tokyo) supplemented with glucose (Nacalai Tesque) $0.1 \% \mathrm{w} / \mathrm{v}$ and Tween $80,0.05 \% \mathrm{w} / \mathrm{v}, 2 \mathrm{ml}$ was inoculated into $200 \mathrm{ml}$ of the same broth $-c$. $(1-5) \times 10^{6} \mathrm{cfu} / \mathrm{ml}$. After aerobic incubation for $4-6 \mathrm{~h}$ at $37^{\circ} \mathrm{C}$ with occasional shaking, cells in the late logarithmic to early stationary growth phase were produced. Next $\mathrm{NaN}_{3}$ (Nacalai Tesque) $0.02 \% \mathrm{w} / \mathrm{v}$ was added to the culture and the preparation was centrifuged at $16000 \mathrm{~g}$ for $30 \mathrm{~min}$ at $0-2^{\circ} \mathrm{C}$. The supernate was passed through a membrane filter $(0.45-$ $\mu \mathrm{m}$ pore) and 50-60 g of polyethylene glycol (PEG) 4000 (Nacalai Tesque) were added to the filtrate. After the PEG had dissolved, the preparation was held for $60 \mathrm{~min}$ in an ice bath with occasional shaking. The solution was centrifuged at $16000 \mathrm{~g}$ for $30 \mathrm{~min}$ at $0-2^{\circ} \mathrm{C}$ and the supernate was removed carefully. The precipitate was dissolved in $2 \mathrm{ml}$ of $0.15 \mathrm{M} \mathrm{NaCl}$ supplemented with $0.01 \mathrm{M} \mathrm{CaCl}_{2}{ }^{8}$ The absence of viable $E$. coli was checked by spreading $0.1 \mathrm{ml}$ of the haemolysin solution on nutrient-agar plates. The haemolysin preparation was stored until needed at below $-20^{\circ} \mathrm{C}$.

\section{Sodium dodecyl sulphate-polyacrylamide gel electrophoresis ( $S D S-P A G E$ )}

SDS-PAGE of the partially purified $E$. col $i$ haemolysin was performed according to the method of Laemmli ${ }^{9}$ with slight modification. Briefly, a separation gel of acrylamide $7.5 \% \mathrm{w} / \mathrm{v}$ containing $0.375 \mathrm{M}$ Tris- $\mathrm{HCl}$, $\mathrm{pH} 8 \cdot 8$, and SDS $0.1 \% \mathrm{w} / \mathrm{v}$ was prepared from a stock solution of acrylamide $30 \% \mathrm{w} / \mathrm{v}$ and $\mathrm{N}, \mathrm{N}$-bis-methylene acrylamide $1 \% \mathrm{w} / \mathrm{v}$. A plate gel $10 \mathrm{~cm}$ long, $13 \mathrm{~cm}$ wide and $1 \mathrm{~mm}$ deep was prepared and polymerised chemically by the addition of tetramethylethylenediamine and ammonium persulphate $0.025 \% \mathrm{v} / \mathrm{v}$. A stacking gel (c. $1 \mathrm{~cm}$ length) of acrylamide $3 \% \mathrm{w} / \mathrm{v}$ containing $0.125 \mathrm{M}$ Tris- $\mathrm{HCl}$, $\mathrm{pH} 6.8$, and SDS $0.1 \% \mathrm{w} / \mathrm{v}$ was polymerised as for the separation gel. The samples contained $0.0625 \mathrm{M}$ Tris-HCl, pH 6.8, SDS $2 \% \mathrm{w} / \mathrm{v}$, glycerol $10 \% \mathrm{v} / \mathrm{v}, 2-$ mercaptoethanol $5 \% \mathrm{v} / \mathrm{v}$ and bromophenol blue $0.001 \% \mathrm{w} / \mathrm{v}$; they were immersed in boiling water for 1.5 min and then $80 \mu \mathrm{l}$ of the sample was applied to the injection port of the gel. Electrophoresis was performed at $10 \mathrm{~mA} /$ gel until bromophenol blue had passed through the stacking gel and then at $25 \mathrm{~mA}$ until the dye reached the bottom of the gel (about $4 \mathrm{~h}$ ). The proteins in the gel were stained for $30 \mathrm{~min}$ with Coomassie Brilliant Blue $0 \cdot 25 \% \mathrm{w} / \mathrm{v}$ in methanol:acetic acid: water $5: 1: 5 \mathrm{v}: \mathrm{v}: \mathrm{v}$. The gel was destained by repeated washing in methanol:acetic acid:water. Mol.-wt markers used were egg albumin $(45 \mathrm{Kda})$, bovine serum albumin $(66 \mathrm{Kda})$, rabbit muscle phosphorylase $\mathrm{B}(97 \cdot 4 \mathrm{Kda}), \beta$-galactosidase (116 Kda), and myosin (205 Kda).

\section{Subcutaneous abscess formation in mice}

Specific pathogen-free mice (Institute of Cancer Research, USA) weighing 20-25 g were give subcutaneous (s.c.) injections of $0 \cdot 1 \mathrm{ml}$ of the bacterial mixtures about $1 \mathrm{~cm}$ from the midline in the shaved lower back. To determine the minimum dose required to produce an abscess in at least $50 \%$ of the mice inoculated, progressive 10 -fold dilutions of cell suspension containing various combinations of bacterial species were injected s.c.

The concentration of each bacterial species in the inoculum was quantified by viable counts on a range of selective media that allowed good growth of only a single species. ${ }^{10,11}$ The basal medium used in the preparation of the selective media for E. coli, K. pneumoniae and $B$. orvatus were semi-defined but those for the other six species were non-defined. The main constituents of the selective media were as follows: $E$. coli (ALPPL: ammonium sulphate-linolate-propionate-penicillin-lincomycin); K. pneumoniae (APLC: ammonium sulphatepenicillin-lincomycin-clindamycin); P.vulgaris (PLVFC: propionate - linolate - vancomycin - furazolidone colimycin); Ent. faecalis (AP: azide-propionate); $S$. aureus (SPP: sodium chloride-propionate-polymyxin); $\boldsymbol{B}$. ovatus (BFAG: ammonium sulphate-gentamicin); $F$. varium (GTNRL: gentamicin - trimethoprim - neomycin-rifampicin-lino-late); Bif. adolescentis (PPL: polymyxin-propionate-linolate); and $C$. perfringens (TGPAC: trimethoprim-gentamicin-propionate-azidecycloserine). Cultures were incubated in air or in an anaerobic jar $\left(\mathrm{CO}_{2} 10 \%, \mathrm{~N}_{2} 90 \%\right)$ for $2-5$ days depending on the species involved. Colonies were then counted and the viable counts $(\mathrm{cfu} / \mathrm{ml})$ were calculated.

\section{Effect on subcutaneous abscess formation of concomitant injection of partially purified E. coli haemolysin with live bacteria}

Mice were given s.c. injections containing $0.05 \mathrm{ml}$ of native $E$. coli haemolysin $\left(125 \mathrm{HU}_{50}\right)$ and $0 \cdot 1 \mathrm{ml}$ of a mixture of five bacteria- $E$. coli ATCC 11775 (nonhaemolytic), Ent. faecalis, B. ovatus, $F$. varium and $C$. perfringens, each in a concentration of $c .10^{6} \mathrm{cfu} / \mathrm{ml}$. Haemolysin inactivated by autoclaving at $120^{\circ} \mathrm{C}$ for 10 min was used as a control.

\section{Viable count of each bacterial species in abscess material}

When well developed abscesses were formed, i.e., 8 10 days after injection of inocula with non-haemolytic $E$. 
coli and 12-14 days after inocula with haemolytic E. coli, mice were killed by ether inhalation. The skin was cleaned with alcohol $80 \%$ and allowed to dry, then the whole abscess (3-4 $\mathrm{mm}$ diameter) was excised aseptically and homogenised in $2 \mathrm{ml}$ of saline with a teflon homogeniser. The homogenate was diluted and $0.1 \mathrm{ml}$ of appropriate dilution was inoculated on to a series of selective media ${ }^{10,11}$ which were incubated as described earlier.

\section{Results}

\section{Abscess forming ability of haemolytic and non- haemolytic E. coli with other bacteria}

When an inoculum containing $c .5 \times 10^{5} \mathrm{cfu}$ of haemolytic E. coli, B. ovatus, Ent. faecalis, $F$. varium and $C$. perfringens was injected into mice, abscesses were formed (table). However, when the nonhaemolytic strain of $E$. coli was tested with the same four species, a concentration of $10^{7} \mathrm{cfu}$ of each was required to produce an abscess (table). In experiments with $E$. coli haemolysin $\left(125 \mathrm{HU}_{50}\right)$ injected concomitantly with an inoculum containing the non-haemolytic $E$. coli strain, abscesses formed with inocula containing only $c .5 \times 10^{5}$ bacteria (fig. 1). When heat inactivated haemolysin was used under the same experimental conditions, no abscesses were formed.

\section{Population of each bacterial species in abscesses}

In abscesses produced by injection of five bacterial species including non-haemolytic $E$. coli, the number of E. coli, Ent. faecalis and B. ovatus remained fairly constant. Numbers of both $F$. varium and $C$. perfringens tended to decrease gradually (fig. 2C, D). However, with inocula

Table. Influence of the presence of haemolytic E. coli and inoculum size on subcutaneous abscess formation in mice

Bacteria in inoculum Inoculum size ( $\log \mathrm{cfu})$

E. coli ATCC 11775
E. coli ATCC 25922
E. faecalis IFO 12969
F. varium ATCC 8501
B. ovatus SU 39
C. perfringens VPI 5201

Number of mice with abscess Number of mice tested

The population of each species in the resultant abscesses is shown in fig. $2 \mathrm{~A}^{*}, \mathrm{~B} \dagger$ and $\mathrm{D} \ddagger$.

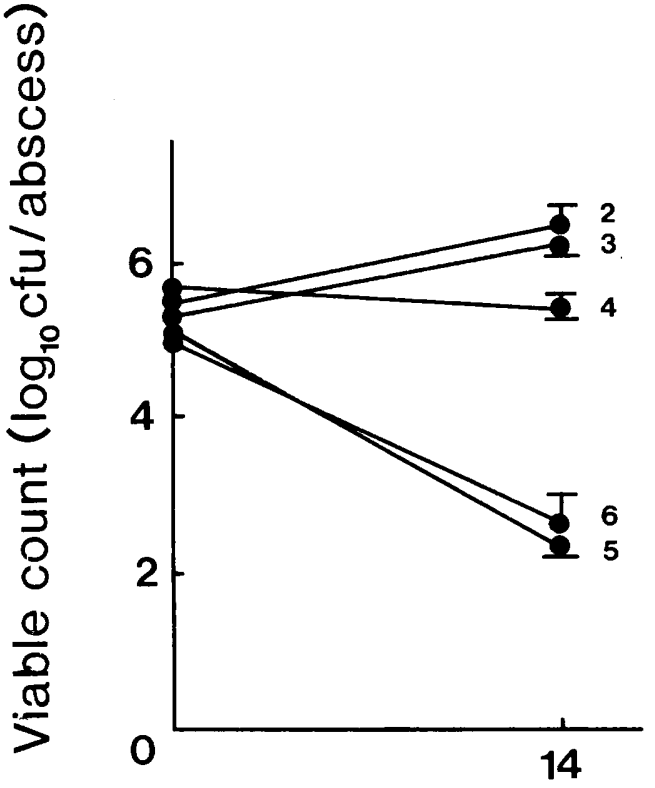

\section{Days after inoculation}

Fig. 1. Population of each species in abscesses formed by concomitant injection of five bacterial species - (2) non-haemolytic E. coli ATCC 11775 ; (3) B. ovatus; (4) Ent. faecalis; (5) C. perfringens; (6) $F$. varium - and partially purified $E$. coli haemolysin. Each result represents a mean of two mice and vertical lines indicate standard deviations (SD).

containing haemolytic $E$. coli (fig. 2 A, B, E) and with those containing non-haemolytic $E$. coli and partially purified $E$. coli haemolysin (fig. 1), the numbers of $B$. ovatus and $E$. coli increased. The final number of $B$. ovatus was apparently influenced by the $E$. coli inoculum size. Greater increases in numbers of both $E$. coli and $B$. ovatus were seen when the original inoculum contained a lower number of $E$. coli. The number of Ent. faecalis (fig. 2A-E) remained fairly constant while the concentrations of $F$. varium and $C$. perfringens decreased rapidly. When nine bacterial species, each in a concentration of $c .10^{5} \mathrm{cfu}$, were injected in mixed culture (fig. 2E), E. coli and B. ovatus again increased rapidly Ent. faecalis and $K$. pneumoniae persisted at levels similar to those at zero time, but $F$. varium, $C$. perfringens, $S$. aureus, $P$. vulgaris and $B$ if. adolescentis decreased rapidly and were not detected in abscesses 14 days after injection.

\section{Properties of purified E. coli haemolysin}

The properties of the partially purified E. coli haemolysin in this study are similar to those 

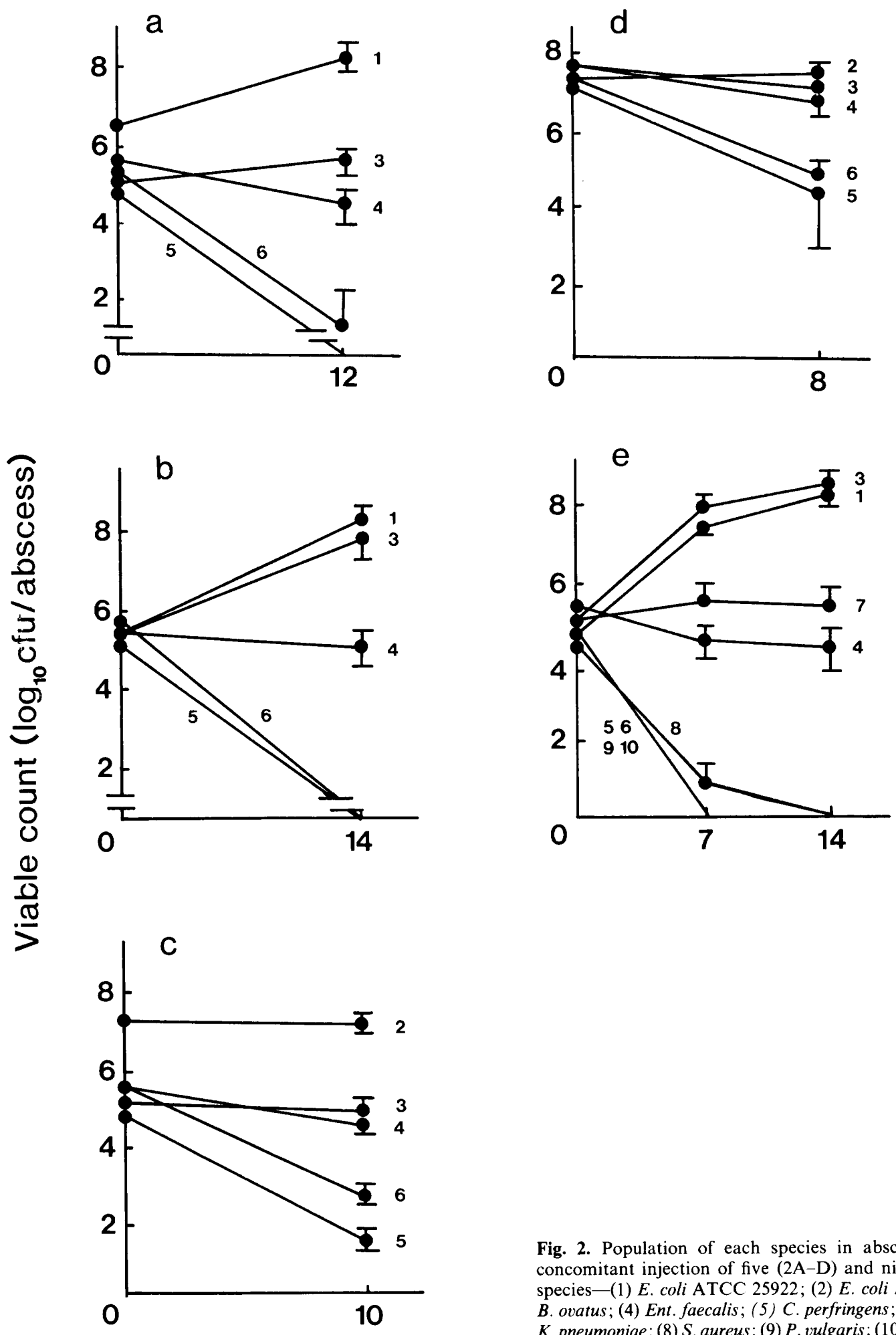

Days after inoculation

Fig. 2. Population of each species in abscesses formed by concomitant injection of five $(2 \mathrm{~A}-\mathrm{D})$ and nine $(2 \mathrm{E})$ bacterial species-(1) E. coli ATCC 25922; (2) E. coli ATCC 11775; (3) B. ovatus; (4) Ent. faecalis; (5) C. perfringens; (6) F. varium; (7) K. pneumoniae; (8) S. aureus; (9) P. vulgaris; (10) Bif. adolescentis. Each result represents a mean value obtained from two mice and vertical lines indicate standard deviations. 
described by Bhakdi et al. ${ }^{12}$ The preparation contained $2500 \mathrm{HU}_{50} / \mathrm{ml}$ and heating of the haemolysin at $56^{\circ} \mathrm{C}$ for $60 \mathrm{~min}$ resulted in loss of $\geq 90 \%$ of haemolytic activity, i.e., the preparation was thermolabile. ${ }^{13}$ SDS-PAGE of the haemolysin showed a single protein band of $c .103 \mathrm{Kda}$.

\section{Discussion}

In 1985, Verweij-van Vught et al. ${ }^{6}$ demonstrated bacterial synergy between $E$. coli and $B$. fragilis in subcutaneous abscess formation in mice and found evidence that this pathogenic synergy was observed in only one of the two combinations of bacteria and was dependent on the properties of $E$. coli. However, no information regarding the possible pathogenic mechanisms involved was presented. The results of this investigation indicate that $E$. coli haemolysin is a factor potentiating pathogenic synergy among several of the predominant bacterial species of the human colonic flora, especially between $E$. coli and $B$. ovatus (a species of the fragilis group of Bacteroides) during subcutaneous abscess formation in mice.

Concomitant injection of $E$. coli haemolysin reduced the number of non-haemolytic $E$. coli required for abscess formation from $c .10^{7} \mathrm{cfu}$ to $10^{5} \mathrm{cfu}$, the latter being the same level as that needed for the haemolytic strain. The haemolysin of $E$. coli is leucotoxic ${ }^{8}$ and may impair the host's cellular defence mechanisms.

The size of the $B$. ovatus population in the abscesses seemed to be determined by the number of haemolytic $E$. coli injected concomitantly. An explanation for this could be that the prolific increase of $E$. coli resulted in the producton of large

\section{REFERENCES}

1. Gorbach S L, Thadepalli H, Norsen J. Anaerobic microorganisms in intraabdominal infection. In: Balows A (eds) Anaerobic bacteria : role in disease. Springfield, Charles C. Thomas, 1975: 399-407.

2. Elhag $\mathbf{K ~ M}$, Alwan $\mathbf{M ~ H , ~ A l - A d n a n i ~} \mathbf{M ~ S}$, Sherif $\mathrm{R} \mathrm{A}$. Bacteroides fragilis is a silent pathogen in acute appendicitis. J Med Microbiol 1986; $21: 245-249$.

3. Onderdonk A B, Weinstein W M, Sullivan N M, Bartlett J G, Gorbach S L. Experimental intra-abdominal abscesses in rats: quantitative bacteriology of infected animals. Infect Immun 1974; 10: 1256-1259.

4. Onderdonk A B, Bartlett J G, Louie T, Sullivan-Seigler N, Gorbach S L. Microbial synergy in experimental intraabdominal abscess. Infect Immun 1976; 13: 22-26.

5. Kelly $\mathbf{M} \mathbf{J}$. The quantitative and histological demonstration of pathogenic synergy between Escherichia coli and quantities of haemolysin which damaged the host defence mechanisms, and also provided a suitable environment for the growth of $B$. ovatus by lowering the redox potential. ${ }^{14}$ However, even in these conditions Ent. faecalis, and K. pneumoniae populations remained stable after injection. In the case of other bacterial species injected with the pathogenic mixture, i.e., $S$. aureus, $P$. vulgaris, Bif. adolescentis, $C$. perfringens and $F$. varium, numbers decreased steadily until most had disappeared from the site of injection. The rapid decrease in numbers of these bacteria may be largely due to host defence activities, and partly to impairment of proliferation by antagonistic effects of co-existing bacteria. ${ }^{15}$

Haemolytic $E$. coli and $B$. ovatus grew prolifically when $c .10^{5} \mathrm{cfu}$ of each were injected with equal numbers of either three or seven other species of colonic flora. Ushijima ${ }^{16}$ has defined these bacteria as strong abscess formers (SAFB). When nonhaemolytic instead of haemolytic cells of $E$. coli were used, an injection of at least $10^{7} \mathrm{cfu}$ was required for abscess formation. In these cases, almost none of the bacteria injected showed an appreciable population increase during the experimental period and Ushijima ${ }^{16}$ has defined such bacteria as weak abscess formers (WAFB).

In human faeces, $E$. coli is the predominant aerobic/facultative species and members of the fragilis group of Bacteroides are the most common anaerobes. ${ }^{17}$ Smith $^{18}$ reported that haemolytic $E$. coli were found in $18 \%$ of human faeces; we found them in $43 \%$ of a group of healthy adults (unpublished data). The prevalence of these haemolytic strains may partly account for the high risk of abscess formation of the SAFB type, especially in cases where the host is compromised by various factors.

Bacteroides fragilis in guinea-pig wounds. $J \mathrm{Med}$ Microbiol 1978; 11 : 513-523.

6. Verweij-van Vught A M J J, Namavar F, Sparrius M, Vel W A C, MacLaren D M. Pathogenic synergy between Escherichia coli and Bacteroides fragilis: studies in an experimental mouse model. J Med Microbiol 1985; 19 : 325-331.

7. Ushijima T, Takahashi M, Ozaki Y. An improved medium for preparation of filterable Escherichia coli haemolysin. J Microbiol Methods 1988; 8: 219-225.

8. Cavalieri S J, Snyder I S. Effect of Escherichia coli alphahemolysin on human leukocyte viability in vitro. Infect Immun 1982; 36: 455-461.

9. Laemmli U K. Cleavage of structural proteins during the assembly of the head of bacteriophage T4. Nature 1970 ; 227: 680-685.

10. Ushijima T, Takahashi M, Ozaki Y. Fourteen selective media facilitate evaluation of populations of co-existing 
fixed bacterial strains of enteric pathogens and normal human faecal flora. $J$ Microbiol Methods $1985 ; 4$ : 189194.

11. Ushijima T, Takahashi M, Tatewaki K, Ozaki Y. A selective medium for isolation and presumptive identification of the Bacteroides fragilis group. Microbiol Immunol 1983; 27 : 985-993.

12. Bhakdi S, Nackman N, Nicaud J M, Holland I B. Escherichia coli hemolysin may damage target cell membrane by generating transmembrane pores. Infect Immun 1986; 52: 63-69.

13. Snyder I S, Koch N A. Production and characteristics of hemolysin of Escherichia coli. J Bacteriol 1966; 91 : 763767.

14. Miyazaki S, Ishii T, Tsuji A et al. Pathogenic factors in mixed infection due to Bacteroides fragilis and other species of bacteria in mice. Nippon Sailzingaku Zasshi $1986 ; 41: 611-617$ (in Japanese).

15. Ushijima T, Ozaki Y. Potent antagonism of Escherichia coli, Bacteroides ovatus, Fusobacterium varium, and Enterococcus faecalis, alone or in combination, for enteropathogens in anaerobic continuous flow cultures. $J$ Med Microbiol 1986; 22: 157-163.

16. Ushijima T. Production of subcutaneous abscess models in mice by injection of mixtures of aerobic and anaerobic bacteria and changes of the population of each bacterium in the abscess. Med Biol 1986; 113 : 407-412 (in Japanese).

17. Finegold S M, Attebery H R, Sutter L. Effect of diet on human fecal flora: comparison of Japanese and American diets. Am J Clin Nutr 1974; 27 : 1456-1469.

18. Smith H W. The haemolysins of Escherichia coli. J Pathol Bacteriol 1963; 85: 197-211. 